\title{
PENGARUH KEPERCAYAAN KEPADA ATASAN, JOB EMBEDDEDNESS, DAN KEPUASAN KERJA TERHADAP KEPERCAYAAN KARYAWAN KEPADA ORGANISASI
}

\author{
THE INFLUENCE OF TRUST IN LEADER, JOB EMBEDDEDNESS ,AND JOB SATISFACTION ON \\ ORGANIZATIONAL TRUST
}

\author{
Mauli Melda Manihuruk*11 dan Tjiptogoro Dinarjo Soehari ${ }^{*}$ \\ *) Universitas Mercu Buana \\ Jl. Raya, Meruya Selatan, Kec. Kembangan, Jakarta 11650, Indonesia
}

\begin{abstract}
This study analyzes the effect of trust in superiors, work attachment and job satisfaction on employee confidence in the organization. This type of research is quantitative. The population is all employees. The sampling technique using non probability sampling method with the type used is purposive sampling (using the Slovin formula with an error of 5\% obtained a sample of sixty seven employees). The method used in this study is multiple linear regression using data processing software tools SPSS version 24.0. The results showed that trust in superiors, work attachment and job satisfaction together (simultaneously) significantly influence employee confidence in the organization. Partially job attachment and job satisfaction have a significant positive effect on employee trust in the organization while trust in superiors has a significant negative effect on employee trust in the organization. Job satisfaction is the most influential variable on employee trust in the organization after the variable work attachment and trust in superiors. The suggestion for the company is that the company should further increase work attachment and employee job satisfaction to obtain high employee trust.
\end{abstract}

Keywords: job embeddedness, trust in leader, job satisfaction, organizational trust

\begin{abstract}
Abstrak: Penelitian ini menganalisis pengaruh kepercayaan kepada atasan, kemelekatan kerja dan kepuasan kerja terhadap kepercayaan karyawan kepada organisasi. Penelitian ini menggunakan pendekatan kuantitatif. Jumlah populasi adalah seluruh karyawan. Teknik pengambilan sampel dengan metode non probability sampling dengan jenis yang digunakan adalah purposive sampling (menggunakan rumus slovin dengan error 5\% didapat sampel sebanyak enam puluh tujuh karyawan). Metode yang digunakan dalam penelitian ini adalah regresi linier berganda dengan menggunakan alat bantu pengolah data software SPSS versi 24.0. Hasil penelitian menunjukkan bahwa kepercayaan kepada atasan, kemelekatan kerja dan kepuasan kerja secara bersama-sama (simultan) berpengaruh signifikan terhadap kepercayaan karyawan kepada organisasi. Secara parsial kemelekatan kerja dan kepuasan kerja berpengaruh signifikan positif terhadap kepercayaan karyawan kepada organisasi sedangkan kepercayaan kepada atasan berpengaruh signifikan negatif terhadap kepercayaan karyawan kepada organisasi. Kepuasan kerja merupakan variabel yang paling besar pengaruhnya terhadap kepercayaan karyawan kepada organisasi setelah variabel kemelekatan kerja dan kepercayaan kepada atasan. Saran untuk perusahaan adalah perusahaan harus lebih meningkatkan kemelekatan kerja dan kepuasan kerja karyawan untuk memperoleh kepercayaan karyawan yang tinggi.
\end{abstract}

Kata kunci: kemelekatan kerja, kepercayaan kepada atasan, kepuasan kerja, kepercayaan organisasi

\footnotetext{
${ }^{1}$ Alamat Korespondensi:

Email: mmelda_m@yahoo.co.id
} 


\section{PENDAHULUAN}

Kepercayaan (trust) berarti keyakinan terhadap integritas, kemampuan atau karakter seseorang atau sesuatu. Dalam sebuah organisasi, manfaat kepercayaan diantaranya adalah terciptanya iklim saling berbagi informasi dan kolaborasi. Ketika seorang karyawan, yakin bahwa ide-idedaninformasi yang disampaikannya akan dihargai, inisiatif dan kreativitasnya akan tumbuh. Pemimpin yang mempercayai anggotanya tidak akan segan-segan mendelegasikan tugas dan wewenang kepada anggotanya. Demikian pula sebaliknya anggota yang mempercayai pemimpinnya akan merasa lebih nyaman dalam menjalankan tugas dan tanggung jawab yang dibebankan kepada mereka. Nicholson et al. (2015) menyebut aktivitas proaktif ini sebagai leadership visibility. Pemimpin yang proaktif juga akan secara kontinu menerapkan komunikasi yang terbuka bagi karyawannya. Karakter pemimpin yang proaktif dianggap mampu memfasilitasi tingkat kepedulian didalam group yang kemudian meningkatkan persepsi positif dari karyawan dalam bentuk pemberdayaan psikologis dan solidaritas karyawan (Houghton et al. 2015).

Kemelekatan kerja adalah salah satu kunci keberhasilan untuk mencapai visi dan misi perusahaan secara optimal, karena karyawan yang memiliki kemelekatan yang tinggi (engaged) adalah karyawan yang konsisten berbicara positif tentang organisasinya baik dalam pergaulan internal maupun pihak luar, seperti: pelanggan atau calon karyawan; dan memiliki keinginan yang kuat untuk tetap tinggal di organisasi, terlepas dari kesempatan yang ada di luar; dan mereka memiliki motivasi dan berusaha memberikan tenaga, waktu dan kompetensi yang mereka miliki terhadap pekerjaannya untuk mencapai kesuksesan organisasi (Hewitt, 2015). Bakker (2014) menjelaskan bahwa karyawan yang engaged dengan perusahaan terdorong untuk melakukan tujuan yang menantang dalam pekerjaannya.

Pada saat ini kerap kali terjadi bahwa karyawan sering merasa belum tercukupi dengan mendapatkan imbalan dari pekerjaan saja sehingga karyawan juga ingin mendapatkan kepuasan dari pekerjaannya. Kepuasan kerja merupakan evaluasi yang menggambarkan seseorang atas perasaan sikapnya senang atau tidak puas dalam bekerja (Rivai, 2004). Sementara itu, variabel kepuasan kerja diukur berdasarkan lima aspek penting dari kepuasan kerja yang dikembangkan oleh Colquitt et al. (2013), yakni kepuasan pembayaran, kepuasan promosi, kepuasan supervisi, kepuasan rekan kerja dan kepuasan terhadap pekerjaan. Kepuasan kerja dapat memberikan rasa semangat karyawan dalam bekerja serta loyalitas karyawan. Karyawan dengan tingkat kepuasan kerja tinggi mempunyai perasaan positif tentang pekerjaan mereka (Fajriyanti, 2018).

Kepercayaan karyawan kepada perusahaan dapat membantu perusahaan meraih profit yang diinginkan, karena produktivitas organisasi ditentukan oleh usaha dan keterikatan karyawan pada pekerjaannya (Hanasyha, 2016). Pekerja yang memiliki kepercayaan dan keterikatan emosional pada pekerjaan yang akan menurunkan ketidakhadiran kerja, menurunkan kecelakaan kerja, dan menunjukkan peningkatan produktifitas sehingga dampaknya akan meningkatkan keuntungan perusahaan (Wagner dan Harter, 2006). Kepercayaan karyawan kepada perusahaan merujuk kepada suatu bentuk keyakinan kepada seorang pimpinan perusahaan bahwa pemimpin tersebut mampu dan akan dalam segala situasi bersikap bijaksana untuk bertindak demi kepentingan orang-orang yang dipimpinnya (Febrina, 2016).

Di era 80-an, Perusahaan General Electric memiliki seorang pemimpin yang hingga saat ini dikenang dalam dunia sumber daya manusia (SDM), Jack Welch berhasil mendorong para manajernya untuk maju, ia memberikan imbalan bonus dan kepemilikan saham $20 \%$ pada manajer teratasnya. Jack Welch berhasil mendapatkan kepercayaan karyawannya. Welch juga dikenal memiliki kepemimpinan yang luar biasa. Welch (2005) dalam Amelung et al. (2017) menyatakan bahwa seorang pemimpin harus memiliki 4-E, yaitu energy, energize, edge dan execute. Ditengah-tengah perubahan dan ketidakpastian saat ini, kepercayaan menjadi landasan bagi kuatnya suatu organisasi. Demi mencapai tujuan perusahaan maka pemimpin organisasi harus dapat menciptakan lingkungan kerja dimana baik antar karyawan maupun karyawan dengan perusahaan memiliki rasa kepercayaan satu sama lain. Keberhasilan suatu organisasi tergantung pada kemampuannya, untuk mengelola berbagai macam sumber daya yang dimilikinya, salah satu yang sangat penting adalah SDM. Dengan kondisi ketersediaan yang terbatas, manajemen SDM menjadi penting agar perusahaan dapat memastikan kesinambungan ketersediaan SDM tersebut dalam mengisi lingkungan kerja yang efektif (Oktariani et al. 2017). SDM senantiasa melekat pada setiap sumber daya organisasi apapun sebagai faktor 
penentu keberadaan dan peranannya dalam memberikan kontribusi ke arah pencapaian tujuan organisasi secara efektif dan efisien (Cholil dan Riani, 2003).

PT. BES menilai SDM sebagai aspek penting di dalam perusahaan. Berbagai perubahan yang terjadi di dalam lingkup bisnis membuat manajemen PT. BES menyadari bahwa pengelolaan SDM sebagai salah satu pilar penggerak terjadinya tujuan perusahaan. Kompetensi karyawan dianggap hal penting oleh perusahaan, karena dengan kompetensi yang sesuai maka karyawan dapat melakukan tugas dan tanggung jawabnya dengan baik, kompetensi karyawan PT. BES dari tahun 2014 sampai dengan 2016 masih di bawah standard yang diharapkan, hal ini terlihat dari grafik gap kompetensi sesuai dengan Gambar 1.

Dari hasil self assessment tiga tahun terakhir pada beberapa kuadaran kompetensi masih terlihat gap dari standard yang dipersyaratkan. Kompetensi yang rendah merupakan salah satu indikator dari rendahnya kepercayaan karyawan kepada organisasi. Apabila karyawan memiliki kepercayaan yang tinggi kepada organisasi maka karyawan akan memberikan kemampuan yang terbaiknya bagi perusahaan. Begitu juga dalam hal kehadiran dan keterlambatan, PT. BES menilai faktor kehadiran dan keterlambatan merupakan salah satu hal yang penting untuk menilai apakah karyawan memiliki kemelekatan kerja terhadap perusahaan. Hal ini dapat diketahui dari banyaknya keterlambatan karyawan pada delapan bulan terakhir di tahun 2017. Ketepatan waktu didalam bekerja merupakan salah satu indikator dari kepercayaan karyawan kepada atasannya, apabila karyawan memiliki kepercayaan kepada atasan maka karyawan tersebut akan berusaha datang tepat waktu didalam bekerja. Adapun grafik keterlambatan PT. BES sesuai dengan Gambar 2.

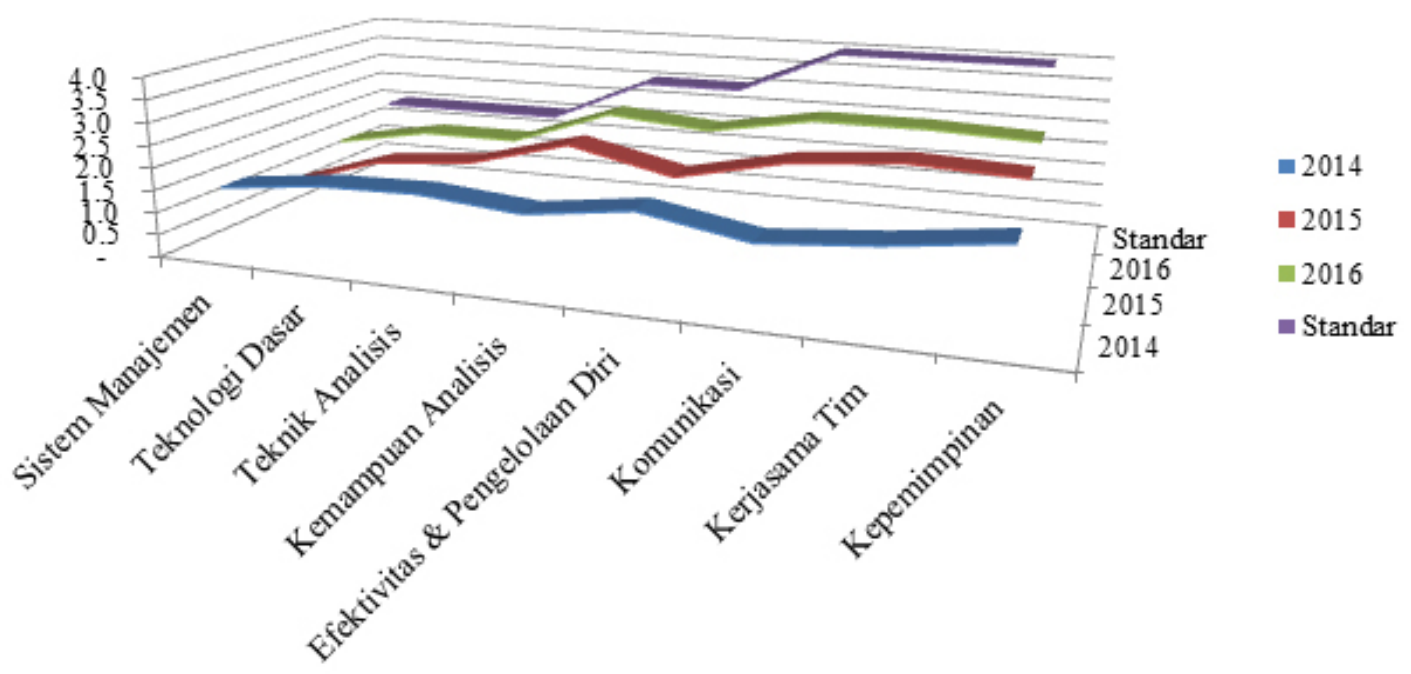

Gambar 1. Grafik Gap Kompetensi Karyawan PT. BES

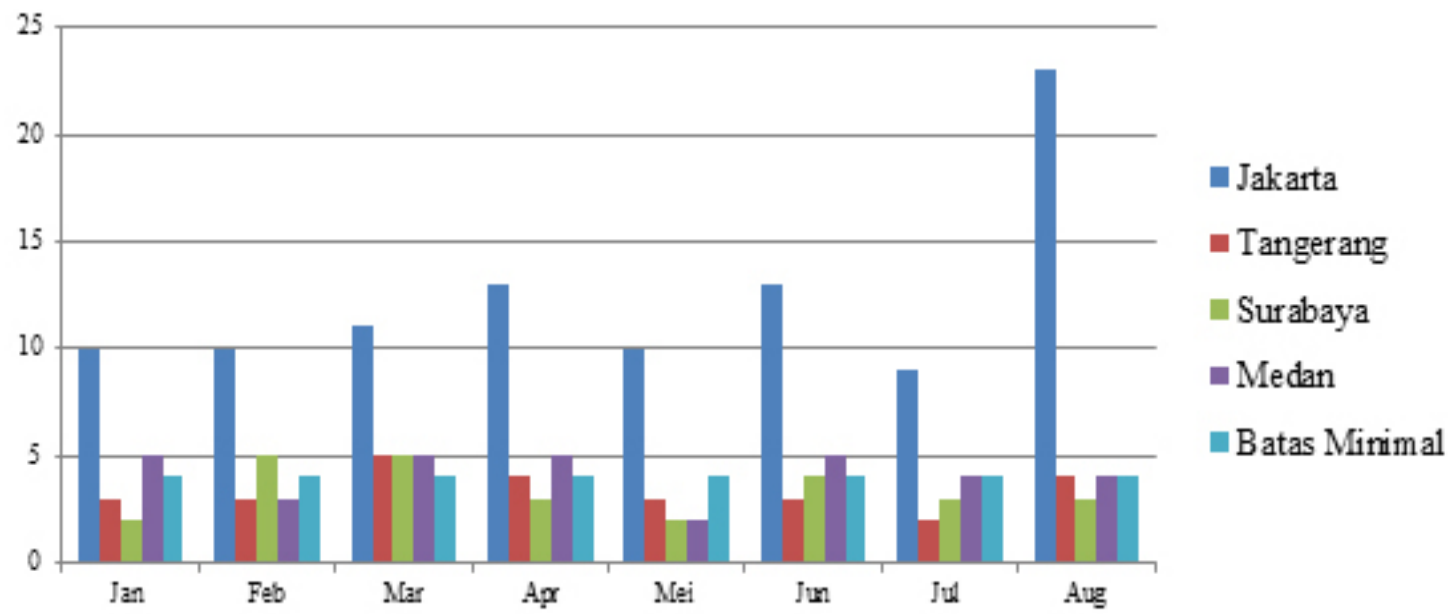

Gambar 2. Grafik Keterlambatan Karyawan PT BES Periode Januari s/d Agustus 2017 
Hasil wawancara yang peneliti lakukan terhadap karyawan, diketahui bahwa menurut karyawan ada beberapa orang atasan yang kurang dapat mengajak dan memotivasi bawahan untuk dapat mencapai target yang ditetapkan perusahaan pada umumnya serta target yang ditetapkan oleh masing-masing unit kerja pada khususnya. Menurut beberapa karyawan, sikap atasan tersebut tidak sesuai dengan apa yang seharusnya menjadi tanggung jawab dari seorang atasan. Karyawan mengharapkan sosok seorang yang menjadi atasan mereka yaitu atasan yang dapat mendorong bawahan untuk mencari metode-metode baru dalam menyelesaikan pekerjaannya, dapat mendengarkan masukan bawahan, serta dapat memperhatikan kebutuhan bawahan termasuk kebutuhan dalam pengembangan karir dan promosi jabatan.Hasil wawancara yang peneliti lakukan terhadap beberapa orang karyawan menunjukkan bahwa karyawan merasa kurang embedded terhadap organisasi. Mereka menyatakan bahwa perusahaan bukanlah menjadi tempat untuk mencapai tujuan karir dan mereka tidak merasa sedih ketika harus meninggalkan perusahaan. Adapun promosi jabatan sejak 2014 sampai tahun 2016 tergambar dalam Gambar 3.

Grafik 3 menunjukkan bahwa promosi jabatan sangat rendah, dari grafik dapat dilihat bahwa promosi di tahun 2014 hanya ada dua orang karyawan yang mendapat promosi jabatan, di tahun 2015 tidak ada karyawan yang mendapat promosi jabatan sedangkan di tahun 2016 hanya ada satu karyawan yang mendapat promosi jabatan. Struktur organisasi yang flat merupakan faktor utama yang membuat sempitnya kesempatan karyawan untuk meraih promosi jabatan. Isu promosi jabatan ini dianggap memberikan pengaruh terhadap kepercayaan karyawan kepada perusahaan. Melihat hal-hal tersebut di atas, manajemen dan peniliti melakukan In Depth Interview (IDI) kepada beberapa karyawan seperti yang tergambar pada Tabel 1.

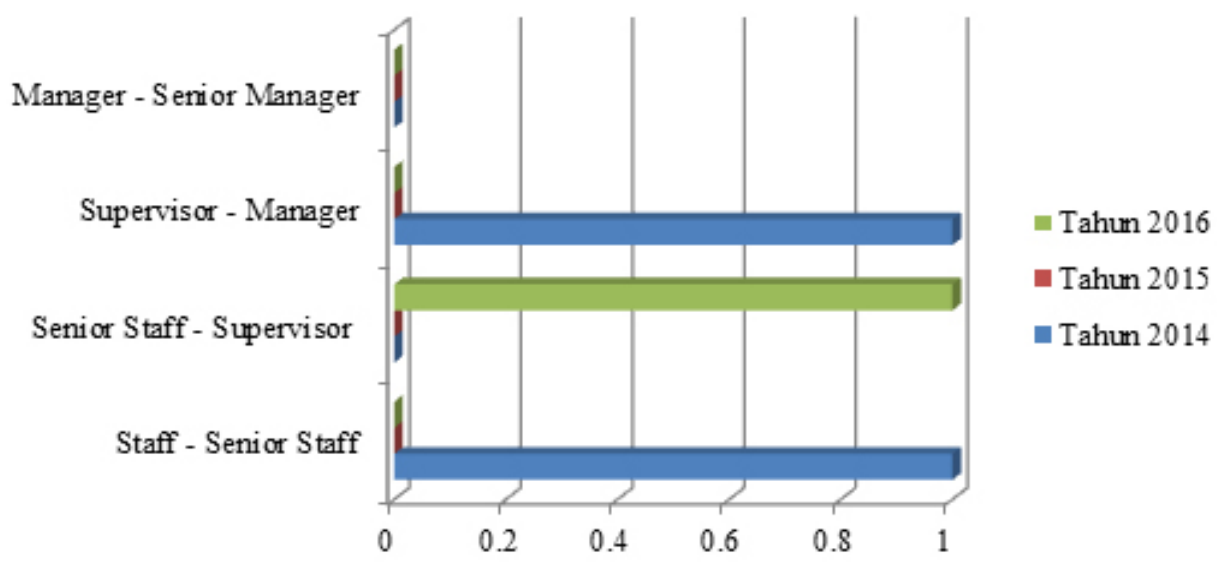

Gambar 3. Grafik Promosi Jabatan PT. BES

Tabel 1. Hasil IDI (In Depth Interview)

\begin{tabular}{|c|c|c|c|c|c|c|}
\hline Pernyataan & STS & TS & $\mathrm{N}$ & $\mathrm{S}$ & SS & TOTAL \\
\hline Saya adalah bagian dari Perusahaan ini & & $37,5 \%$ & $25 \%$ & $25 \%$ & $12, \%$ & $100 \%$ \\
\hline $\begin{array}{l}\text { Perusahaan ini memiliki komitmen dan kepedulian terhadap } \\
\text { karyawannya }\end{array}$ & & $12,5 \%$ & $62,5 \%$ & $25 \%$ & & $100 \%$ \\
\hline Atasan saya membantu anda dalam hal pekerjaan & & & $25 \%$ & $75 \%$ & & $100 \%$ \\
\hline Atasan saya memberikan apresiasi terhadap hasil pekerjaan saya & & $12,5 \%$ & $25 \%$ & $50 \%$ & $12,5 \%$ & $100 \%$ \\
\hline Saya memiliki kerjasama yang baik dengan rekan kerja & & & $25 \%$ & $75 \%$ & & $100 \%$ \\
\hline Saya merasa sedih jika harus meninggalkan Perusahaan ini & & $50 \%$ & $37,5 \%$ & & $12,5 \%$ & $100 \%$ \\
\hline $\begin{array}{l}\text { Gaji yang diberikan Perusahaan sesuai dengan pekerjaan yang saya } \\
\text { lakukan }\end{array}$ & $12,5 \%$ & & $12,5 \%$ & $75,5 \%$ & & $100 \%$ \\
\hline Secara keseluruhan saya merasa happy bekerja di Perusahaan ini & & $12,5 \%$ & $62,5 \%$ & $25 \%$ & & $100 \%$ \\
\hline
\end{tabular}


Secara keseluruhan dari IDI (Tabel 1) maka dapat disintesa bahwa: Kepercayaan karyawan kepada organisasi masih rendah sedangkan kepercayaan kepada atasan cukup baik, kemelekatan kerja dilihat dari kerjasama individu cukup baik sedangkan jika dilihat dari kenyamanan fisik atau psikologis karyawan secara keseluruhan masih rendah. Kepuasan kerja dilihat dari segi kepuasan gaji yang diberikan perusahaan cukup baik sedangkan dilihat dari kepuasan karyawan secara keseluruhan mereka mengatakan netral. Hasil IDI dan data sekunder tersebut memberikan dasar bagi peneliti untuk membuktikan adanya masalah yang ada pada SDM di perusahaan, terlihat dari masih rendahnya kepercayaan karyawan kepada organisasi. Data menunjukkan masih terdapatnya gap kompetensi yang dimiliki oleh karyawan. Kompetensi yang rendah merupakan salah satu indikator dari rendahnya kepercayaan karyawan kepada organisasi. Begitu juga terlihat dari masih rendahnya kepercayaan karyawan kepada atasan. Hasil wawancara yang dilakukan peneliti kepada beberapa karyawan menunjukkan ada beberapa orang atasan yang kurang dapat mengajak dan memotivasi bawahan untuk dapat mencapai target yang ditetapkan perusahaan pada umumnya serta target yang ditetapkan oleh masing-masing unit kerja pada khususnya. Data sekunder menunjukkan bahwa masih banyak terdapat keterlambatan karyawan setiap bulannya melebihi target yang ditetapkan perusahaan. Ketepatan waktu didalam bekerja merupakan indikator dari kepercayaan karyawan kepada atasannya, apabila karyawan memiliki kepercayaan kepada atasan maka karyawan tersebut berusaha datang tepat waktu didalam bekerja. Berdasarkan IDI yang dilakukan oleh peneliti, didapatkan bahwa kemelekatan kerja jika dilihat dari kenyamanan fisik atau psikologis karyawan secara keseluruhan masih rendah. Hal tersebut juga diperkuat dengan data sekunder menunjukkan bahwa struktur organisasi yang flat membuat karyawan merasa perusahaan bukanlah menjadi tempat tujuan karir dari karyawan. Sebagian besar karyawan masih merasa kurang puas terutama mengenai promosi jabatan. Data sekunder menunjukkan bahwa perusahaan masih kurang memberikan kesempatan karyawan untuk meraih promosi jabatan.

Kajian penelitian terdahulu yang relevan dengan kepercayaan kepada atasan, kemelekatan kerja, kepuasan kerja terhadap kepercayaan karyawan kepada organisasi di beberapa organisasi digunakan oleh peneliti sebaga dasar referensi dalam rangka mempertajam penelitian ini antara lain: Penelitian
Kusumaputri (2014), penelitian ini bertujuan untuk menganalisis pengaruh kepercayaan kepada atasan terhadap komitmen afektif terhadap organisasi. Penelitian ini menunjukkan bahwa semakin tinggi kepercayaan pengurus (atasan) maka semakin tinggi pula komitmen afektif terhadap organisasi. Penelitian Peachey et al. (2013) bertujuan untuk menganalisis pengaruh job embeddedness terhadap komitmen karyawan. Penelitian ini menunjukkan bahwa turnover karyawan akan lebih kuat bila embeddedness karyawan rendah. Turnover karyawan yang tinggi menunjukkan bahwa komitmen karyawan kepada perusahaan rendah. Penelitian Farida (2016) bertujuan menganalisis pengaruh kepuasan kerja terhadap kepercayaan krayawan kepada organisasi. Penelitian ini menunjukkan kepuasan kerja berpengaruh positif dan signifikan terhadap kepercayaan karyawan kepada organisasi. Penelitian Rusdin (2015) menyatakan bahwa quality of work life berpengaruh positif dan signifikan terhadap kemelekatan karyawan.

Perbedaan penelitian terdahulu dengan penelitian yang dilakukan dapat dilihat dari beberapa hal, yaitu objek penelitian, tempat penelitian, metode analisis dan jumlah responden. Tujuan penelitian ini adalah menganalisis pengaruh kepercayaan kepada atasan terhadap kepercayaan karyawan kepada organisasi PT. BES, menganalisis pengaruh kemelekatan kerja terhadap kepercayaan karyawan kepada organisasi PT. BES, menganalisis pengaruh kepuasan kerja terhadap kepercayaan karyawan kepada organisasi PT. BES dan menganalisis pengaruh kepercayaan kepada atasan, kemelekatan kerja, kepuasan kerja secara bersamasama terhadap kepercayaan karyawan kepada organisasi PT. BES. Penelitian ini difokuskan untuk mengukur pengaruh antara kepercayaan karyawan kepada atasan, kemelekatan kerja dan kepuasan kerja terhadap kepercayaan kepada organisasi PT. BES. Responden dalam penelitian ini adalah seluruh karyawan PT. BES yang berjumlah 67 orang. Data yang dianalisis dalam penelitian ini adalah data primer dan sekunder. Metode analisis menggunakan software SPSS versi 24.0

\section{METODE PENELITIAN}

Penelitian ini dilakukan di PT. BES yang beralamat di Kamboja Raya, Jakarta Barat. Penelitian dilaksanakan selama enam bulan, yaitu pada bulan Maret 2017 sampai dengan Agustus 2017. Data yang digunakan pada penelitian ini adalah data primer dan data sekunder. 
Data primer biasanya diperoleh dari survei lapangan yang menggunakan semua metode pengumpulan data ordinal (Sugiyono, 2014). Data sekunder, yaitu data yang diperoleh dari laporan-laporan dan informasi lain yang bersumber dari literatur, dokumen dan informasi lain yang berhubungan dengan penulisan ini. Data primer secara khusus dikumpulkan untuk menjawab pertanyaan penelitian yang diperoleh langsung dari pengisian kuesioner oleh responden. Pengolahan hasil dari data primer yang berupa data kualitatif akan diolah menjadi data kuantitatif dengan skala likert. Sementara itu, scoring menggunakan angka satu sampai dengan lima hanya merupakan kode untuk mengetahui mana yang lebih tinggi dan mana yang lebih rendah. Penilaian dimulai pada sangat tidak setuju dengan bobot terendah dan sangat setuju dengan bobot tertinggi. Penelitian ini merupakan penelitian deskriptif kuantitatif, variabel dalam penelitian ini adalah kepercayaan karyawan kepada organisasi sebagai variabel dependen (Y) sedangkan variabel independen $(\mathrm{X})$ adalah kepercayaan kepada atasan (X1), kemelekatan kerja (X2), dan kepuasan kerja (X3). Populasi dalam penelitian ini adalah karyawan PT. BES yang berjumlah 80 orang dengan sampel berjumlah 67 orang, adapun karakteristik responden dalam penelitian ini sesuai dengan Tabel 2.

Berdasarkan kerangka pikir penelitian maka hipotesis penelitian yang diajukan adalah sebagai berikut :

H1: Kepercayaan kepada atasan berpengaruh positif dan signifikan terhadap kepercayaan karyawan kepada organisasi. Hipotesis ini didukung oleh Kusumaputri (2014) yang menyatakan bahwa semakin tinggi kepercayaan kepada pengurus (atasan) maka semakin tinggi pula komitmen afektif terhadap organisasi.

H2: Kemelekatan kerja berpengaruh positif dan signifikan terhadap kepercayaan karyawan kepada organisasi. Hipotesis ini didukung oleh Peachey et al. (2013) yang menyatakan bahwa job embeddedness memoderatori hubungan negatif antara komitmen karyawan dan turnover akan lebih kuat bila embeddedness lebih rendah.

H3: Kepuasan kerja berpengaruh positif dan signifikan terhadap kepercayaan karyawan kepada organisasi. Hipotesis ini didukung oleh pnelitian Farida (2016) yang menyatakan bahwa kepercayaan dan komitmen organisasi berpengaruh positif dan signifikan terhadap kepuasan kerja, demikian juga dengan hasil penelitian Kwasira dan Waigwa (2014) yang menyatakan bahwa kepuasan kerja memiliki hubungan positif dengan employee engagement. Hasil penelitian Deshwal (2015) juga menunjukkan bahwa job satisfaction memiliki hubungan positif yang signifikan terhadap employee engagement karyawan yang bekerja di hospitality sector from Gurgaon and Ghaziabad region.

H4: Kepercayaan kepada atasan, kemelekatan kerja dan kepuasan kerja berpengaruh positif dan signifikan terhadap kepercayaan kepada organisasi secara bersama-sama.

\section{HASIL}

Hasil uji validitas dan realibilitas menunjukkan bahwa data yang diperoleh dari responden adalah valid dan reliabel sehingga memenuhi persyaratan untuk dianalisa lebih lanjut. Hasil pengujian asumsi klasik juga menunjukkan bahwa syarat model penelitian regresi sudah terpenuhi dengan adanya data yang berdistribusi normal, tidak ada gejala multikolinieritas dan tidak ada gejala heterokedastisitas. Adapun persamaan regresi berganda yang diperoleh adalah sebagai berikut:

$$
\mathrm{Y}=0,786+0,080 \mathrm{X}_{1}+0,275 \mathrm{X}_{2}+0,480 \mathrm{X}_{3}
$$

Penjelasan persamaan regresi yang diperoleh tersebut adalah sebagai berikut:

Konstanta sebesar 0,786 menyatakan bahwa jika tidak ada kepercayaan kepada atasan, kemelekatan kerja dan kepuasan kerja maka skor total kepercayaan karyawan kepada organisasi adalah sebesar 0,786 . Nilai koefisien regresi X1 (kepercayaan karyawan kepada atasan) sebesar 0,080 menyatakan bahwa setiap penambahan skor kepercayaan kepada atasan sebesar 1 maka akan meningkatkan kepercayaan karyawan kepada organisasi sebesar 0,080. Variabel kepercayaan kepada atasan (X1) dalam penelitian ini ternyata memiliki pengaruh positif terhadap kepercayaan karyawan kepada organisasi (Y), jika kepercayaan kepada atasan ditingkatkan, maka kepercayaan karyawan kepada organisasi akan tercapai dengan baik. Nilai koefisien regresi X2 (kemelekatan kerja) sebesar 0,275 menyatakan bahwa setiap penambahan skor kemelekatan kerja sebesar 1 maka akan meningkatkan kepercayaan karyawan kepada organisasi sebesar 0,275. Variabel kemelekatan kerja (X2) dalam penelitian ini memiliki pengaruh positif terhadap kepercayaan karyawan kepada organisasi (Y), jika kemelekatan kerja karyawan ditingkatkan maka kepercayaan karyawan kepada organisasi akan tercapai 
dengan baik pula. Nilai koefisien regresi X3 (kepuasan kerja) sebesar 0,480 menyatakan bahwa setiap penambahan skor kepuasan kerja sebesar 1 maka akan meningkatkan kepercayaan karyawan kepada organisasi sebesar 0,480. Variabel kepuasan kerja (X3) memiliki pengaruh paling besar terhadap kepercayaan karyawan kepada organisasi. Hal tersebut menunjukkan bahwa variabel kepuasan kerja berpengaruh positif terhadap kepercayaan kepada organisasi. Jika kepuasan kerja karyawan ditingkatkan maka kepercayaan karyawan kepada organisasi juga akan meningkat. Nilai korelasi berganda dari hasil analisis regresi linier berganda adalah sebesar RSq $=0,549$. Hal ini menunjukkan bahwa persentase sumbangan pengaruh variabel kepercayaan karyawan kepada atasan, kemelekatan kerja dan kepuasan kerja terhadap kepercayaan karyawan kepada organisasi adalah sebesar 54,9\% sedangkan sisanya dipengaruhi oleh variabel lain yang tidak dimasukkan dalam model penelitian ini. Hasil analisis regresi linier berganda diperoleh sebagai berikut:

\section{Variabel kepercayaan kepada atasan (X1)}

Nilai $\mathrm{t}_{\text {hitung }}<$ ttabel $(0,519<1,669)$ dan nilai Sig. 0,606 $>0,05$ maka hal tersebut memiliki kesimpulan bahwa variabel kepercayaan kepada atasan berpengaruh positif dan tidak signifikan terhadap kepercayaan karyawan kepada organisasi. Hal ini dapat diartikan bahwa perubahan yang terjadi pada faktor kepercayaan terhadap atasan menyebabkan adanya peningkatan kepercayaan karyawan kepada organisasi walaupun tidak signifikan.

Variabel kemelekatan kerja (X2)

Nilai $\mathrm{t}_{\text {hitung }}>\mathrm{t}_{\text {tabel }}(2,29>1,669)$ dan nilai Sig $<0,05$ maka hal tersebut memiliki kesimpulan bahwa variabel kemelekatan kerja memiliki pengaruh positif dan signifikan terhadap kepercayaan karyawan kepada organisasi. Hal ini dapat diartikan bahwa perubahan yang terjadi pada faktor kemelekatan kerja menyebabkan adanya peningkatan organisasi.

Variabel kepuasan kerja (X3)

Nilai $t_{\text {hitung }}>t_{\text {tabel }}(3,508>1,669)$ dan nilai Sig. $<0,05$, maka dengan demikian dapat disimpulkan bahwa variabel kepuasan kerja memiliki pengaruh yang positif dan signifikan terhadap kepercayaan karyawan kepada organisasi. Hal ini dapat diartikan bahwa perubahan yang terjadi pada faktor kepuasan kerja menyebabkan adanya peningkatan kepercayaan karyawan kepada organisasi.

Adapun hasil uji $\mathrm{F}$ menunjukkan bahwa secara bersama-sama variabel kepercayaan kepada atasan, kemelekatan kerja dan kepuasan kerja berpengaruh terhadap kepercayaan karyawan kepada organisasi. Hal ini sekaligus menerima hipotesis bahwa kepercayaan kepada atasan, kemelekatan kerja dan kepuasan kerja secarabersama-samaberpengaruhterhadapkepercayaan karyawan kepada organisasi. Untuk memastikan kembali hasil tersebut diatas maka peneliti melakukan pengujian kembali dengan cara mentrasnformasi data ke dalam bentuk Ln dan didapatkan hasil uji t bahwa variabel kepuasan kerja memiliki pengaruh yang positif dan signifikan terhadap kepercayaan kepada organisasi (Nilai $\left.t_{\text {hitung }}>\mathrm{t}_{\text {tabel }}=5,606>1,669\right)$ dimana nilai sig 0,00 $<0,005$ ). Hasil uji determinasi $\mathrm{Ln}$ nilai $\mathrm{RSq}=0,525$ konsisten dengan RSq sebelumnya dan nilai $\mathrm{F}=23,21$ kosisten menunjukkan bahwa secara bersama-sama variable kepercayaan kepada atasan, kemelekatan kerja dan kepuasan kerja berpengaruh terhadap kepercayaan karyawan kepada organisasi $\left(\mathrm{F}_{\text {hitung }}>\mathrm{F}_{\text {tabel }}=23,201>\right.$ 2,75 dimana nilai sig $0,000<0,05$ ).

\section{Implikasi Manajerial}

Hal penting yang dapat dijadikan implikasi manajerial bagi manajemen PT. BES adalah mengenai kepuasan karyawan. Perusahaan diharapkan dapat memberikan beberapa program yang bisa meningkatkan kepuasan karyawan kepada perusahaan. Tingginya kepuasan karyawan dapat memberikan jaminan bahwa karyawan tersebut dapat memiliki rasa kepercayaan kepada perusahaan dan pada akhirnya akan memberikan dampak positif kepada perusahaan itu sendiri. Pemberian dukungan kepada karyawan dipercaya dapat meningkatkan kepercayaan karyawan kepada perusahaan, selain itu interaksi harmonis antar manajemen dan karyawan juga dapat diambil sebagai salah satu solusi dalam meningkatkan kepercayaan karyawan kepada perusahaan. Begitu juga dengan komunikasi antara atasan dan bawahan, kemudahan berkomunikasi dengan atasan dianggap memberikan dampak terhadap meningkatnya kepercayaan karyawan kepada perusahaan antara lain melalui: pemberian informasi mengenai target kerja dengan rinci kepada karyawan, memberikan bimbingan baik secara teknis dan bimbingan moral mengenai pelaksanaan pekerjaan 
dan memberi solusi untuk mengatasi permasalahan kerja. Begitu juga peningkatan terhadap kesempatan yang sama untuk memperoleh promosi jabatan disertai dengan peningkatan terhadap gaji karyawan.

\section{KESIMPULAN DAN SARAN}

\section{Kesimpulan}

Variabel kepercayaan kepada atasan secara parsial berpengaruh positif dan tidak signikan terhadap kepercayaan karyawan kepada organisasi. Dimensi yang memiliki korelasi paling rendah dari variabel kepercayaan kepada atasan adalah dimensi believable. Hal ini menunjukkan bahwa kepercayaan karyawan kepada atasan tidak secara otomatis membuat karyawan tersebut menjadi percaya kepada organisasi dan begitu juga sebaliknya. Variabel kemelekatan kerja secara parsial berpengaruh positif terhadap kepercayaan karyawan kepada organisasi. Dimensi fit adalah dimensi yang memiliki korelasi paling tinggi dengan dimensi kepercayaan karyawan kepada organisasi. Hal ini menunjukkan bahwa kesesuaian pekerjaan berdasarkan latar belakang pendidikan dan minat karyawan menjadi salah satu faktor yang paling menentukan untuk seorang karyawan dapat percaya kepada organisasinya. Variabel kepuasan kerja merupakan variabel yang paling kuat mempengaruhi kepercayaan karyawan kepada organisasi. Hasil penelitian tersebut sejalan dengan hasil IDI yang menunjukkan bahwa sebagian besar dari karyawan merasa pemberian gaji yang diberikan oleh perusahaan sudah cukup baik dan hal tersebutlah yang paling diharapkan oleh karyawan untuk meningkatkan kepercayaan karyawan kepada organisasi. Variabel kepercayaan kepada atasan, kemelekatan kerja dan kepuasan kerja secara bersamasama atau simultan berpengaruh positif dan signifikan terhadap kepercayaan karyawan kepada organisasi. Dengan demikian dapat disimpulkan bahwa apabila organisasi ingin meningkatkan rasa kepercayaan karyawan kepada organisasi maka kepercayaan kepada atasan, kemelekatan kerja dan kepuasan kerja dapat menjadi perhatian utama dan diperhitungkan dalam menentukan kebijakan-kebijakan organisasi. Variabel kepuasan kerja adalah variabel yang memiliki pengaruh paling besar terhadap kepercayaan karyawan kepada organisasi, terutama dimensi promosi, dengan demikian organisasi harus meninjau ulang kembali sistem promosi yang ada.

\section{Saran}

Bagi perusahaan untuk melakukan penelitian lanjutan yang dikhususkan pada variabel kepercayaan kepada atasan untuk mendapatkan informasi atau fakta empiris tentang hal-hal yang dapat meningkatkan kondisi kepercayaan kepada atasan di dalam organisasi untuk kemudian berkomitmen melakukan perubahanperubahan guna terciptanya lingkungan organisasi yang nyaman dan terbangun kepercayaan kepada atasan. Perusahaan harus dapat mempertahankan kemelekatan kerjakaryawan sehingga dapatmembantu meningkatkan kepercayaan karyawan kepada organisasi. Variabel kepuasan kerja merupakan variabel dengan pengaruh yang paling kuat dan signifikan pada penelitian ini. Oleh karena itu, hal ini sangat penting untuk mendapatkan perhatian yang besar dari perusahaan dan dapat lebih ditingkatkan lagi terutama sistem promosi, pekerjaan, dan supervisi.

\section{DAFTAR PUSTAKA}

Bakker AB. 2014. Daily fluctuations in work engagement: An overview and current directions. European Psychologist 19(4):227-236.

Cholil M, Riani, AS, 2003. Hubungan kepuasan kerja dan karakteristik individual dengan komitmen organisasional tenaga dosen ekonomi perguruan tinggi swasta kota Surakarta. Jurnal Perspektif $8(1)$.

Colquitt JA, Lepine JA, Wesson MJ. 2013. Organizational Behavior: Improving Performance and Commitment in the Workplace. New York:McGraw-Hill.

Deshwal S. 2015. A study of job satisfaction in relation to employee engagement. International Journal of Applied Research 1(9):303-304.

Djumarno, Hendrawan. 2016. Trust, Networking, Integrity Menjadi SDM Unggul, Edisi Pertama, Jakarta: Penerbit ASIK Generation.

Fajrianti F, Panjaitan N, Kuswanto S. 2018. Pengaruh budaya organisasi dan kohesivitas kelompok terhadap kepuasan kerja karyawan di PT. Bank BNI Syariah. Jurnal Aplikasi Manajemen dan Bisnis 5(3).

Febrina R. 2016. Analisis pengaruh leadership trust dan leadership visibility terhadap employee psychological safety karyawan perusahaan target akuisisi. Jurnal Manajemen dan Bisnis Sriwijaya 14(3). 
Hanasya J.2016. Improving employee productivity through work engagement: Empirical evidence from higher education sector. Industrial Journal of Industrial engineering Computations 6:6170.

Hewitt A. 2015. Aon Hewitt's Model of Employee Engagement. AON Inc.

Houghton JD et al. 2015. Sharing is caring: Toward a model of proactive caring through shared leadership. Human Resource Management Review 25:313-327.

Kaswan. 2017. Psikologi Industri dan Organisasi. Penerbit Alfabeta Bandung.

Kwasira J, Waigwa MN. 2014. An assessment of the relationship between job satisfaction and employee engangement among teachers inNakuru North Sub-Country. International Journal of Science and Research 3(10):13351339.

Oktariani D, Hubeis A, Sukandar D. 2017. Kepuasan kerja generasi $\mathrm{X}$ dan generasi $\mathrm{Y}$ terhadap komitmen kerja di Bank Mandiri Palembang. Jurnal Aplikasi Bisnis dan Manajemen 3(1).

Putri dan Kusumaputri. 2014. Kepercayaan (trust) terhadap pengurus organisasi dan komitmen afektif pada organisasi mahasiswa daerah di Yogyakarta. Jurnal Psikologi Interaktif 2(1).
Rao-Nicholson R, Khan Z, Stokes P. 2015. Making great minds think alike: Emerging market multinational firms' leadership effects on targets' employee psychological safety after cross-border mergers and acquisitions. International Business Review 25: 103-113.

Rivai V. 2004. Manajemen Sumber Daya Manusia untuk Perusahaan; dari Teori ke Praktek. Jakarta: PT. Raja Grafindo Persada.

Robbins SP, Judge TA. 2015. Perilaku Organisasi, edisi 16, Penerbit Salemba Empat.

Rusdin. 2015. Faktor kualitas kehidupan kerja dan keterlakatan pegawai: survey terhadap manajer madya pada badan usaha milik Negara di Indonesia. Business Management Journal 11(2):83-119. http://doi.org/10/30813/bmj. vlli2.627.

Sugiyono. 2014. Metode Penelitian Pendidikan Pendekatan Kuantitatif dan Kualitatif. Bandung: Penerbit Alfabeta.

Syarifah IF. 2016. Pengaruh kepercayaan dan komitmen organisasi terhadap motivasi dan kepuasan kerja. Jurnal Kependidikan 46(1).

Wagner R, Harter JK. 2006. 12: The Great Elements of Managing. Washington DC: The Gallup Organization. 